\title{
OXYTETRACYCLINE RESIDUES IN THAI PANGAS PANGASIANODON HYPOPHTHALMUS SAMPLED FROM SYLHET SADAR UPAZILA, BANGLADESH
}

\author{
Md. Motaher Hossain*, A. K. Apurbo Barman, Md. Matiur Rahim¹, Mohammad \\ Tariqul Hassan ${ }^{1}$, Maksuda Begum ${ }^{1}$ and Debarshi Bhattacharjee \\ Department of Fisheries Technology and Quality Control, Sylhet Agricultural \\ University, Sylhet, Bangladesh
}

Intensive culture of Thai Pangas (Pangasianodon hypophthalmus; Sauvage, 1878) in freshwater ponds is much more popular in the aquaculture sector of Bangladesh (Ali et al. 2016). Like other cultivated catfishes, pangas is popular among fish farmers and well-known for its faster growth, easy culture system, possessing hardy characteristics, good survival rates, ability to survive at high stocking densities, high disease resistance and tolerance of a wide range of environmental parameters (Begum et al. 2012). As a result in existing aquaculture practices of Bangladesh recent extension of commercial pellet-fed culture of pangas and tilapia together now account for near to $29 \%$ of total aquaculture production (Belton et al. 2011).

In modern culture system antibiotics are being employed prophylactically and therapeutically to protect fish from bacterial diseases and as well as for growth promotion (Avsever et al. 2010). Where, oxytetracycline (OTC), a group of tetracyclines is the primary used antibacterial in most aquaculture production (Erdogdu 2012). Farm cultured pangas are mainly affected by red spot disease or rectal/anal protrusion problems (Ali et al., 2016). In recent years it is richly used in intensive pangas farms to treat fish disease in freshwater aquaculture of Bangladesh (Ali et al. 2016). But oxytetracycline and other antibiotics have not always been used in a control manner in aquaculture (FAO/WHO 2003).

Heavy and indiscriminate use of antibiotic lead to unwanted deposition of their residues in edible tissues which have a public health risks. On the other hand residues of antimicrobials also result in lowering the market value of aquaculture goods (Heuer et al. 2009, Sapkota et al. 2008). Due to potential hazards associated with the presence of antibiotic residues in fish, there is a global concern about the eating of aquatic food having low levels of antibiotics. In Bangladesh, indiscriminate use of oxytetracycline in aquaculture have been

${ }^{1}$ Author for correspondence: <motaher03@yahoo.com>. ${ }^{1}$ Institute of Food science and Technology, Bangladesh Council of Scientific and Industrial Research, Dhaka-1205, Bangladesh.

(C) 2018 Zoological Society of Bangladesh DOI: http://dx.doi.org/10.3329/bjz.v46i1.37629 
documented (Ali et al. 2016) but monitoring of its residues in fishes is limited. The present study was designed to determine the occurrence of oxytetracycline residues in pangas fish which are marketed in local fish markets of Sylhet region of Bangladesh.

Experimental fish were collected from four selected fish markets of Sylhet Sadar Upazila, namely Kazir Bazar, Balucharb Noya Bazar, Mejor Tilah Bazar and Tuker Bazar under the study area. For analysis 24 samples of Thai Pangas (850 to $1000 \mathrm{gm}$ ) were collected between the periods March 2016 to August 2016, in separate marked polythene bags and were kept in an ice box. Then transported to Microbiology Laboratory of Department of Fisheries Technology and Quality Control, Sylhet Agricultural University and kept in a deep refrigerator. For analyzing purpose then the samples were transported to Food Toxicology Laboratory of Bangladesh Council of Scientific and Industrial Research, Dhaka with icing condition and kept in a deep refrigerator at $-20^{\circ} \mathrm{C}$ for promote analysis.

Oxytetracycline residue in fish samples was detected by High Performance Liquid Chromatography (Agilent series 1100). Calibration curve was prepared from injecting corresponding concentrations of oxytetracycline standard solution of $25,50,75,100,125$ and $150 \mathrm{ppb}$. The detection limit for oxytetracycline was $23.62 \mathrm{ppb}$. The mean retention times (RT) of the oxytetracyclines were found between 4.031 and 4.25 minutes.

After adequate thawing $5.0 \mathrm{~g}$ of partially thawed intact samples was taken into $50 \mathrm{ml}$ polypropylene centrifuge tubes. After addition of extraction solution to each sample and homogenization samples were uniformly blended and added to centrifuge tube. Tubes were capped and shaken 10 minutes at speed. Contents of tubes were centrifuged at a minimum $8000 \mathrm{rpm}$ for 20 minutes at approximately $15^{\circ} \mathrm{C}$. Supernatants were poured into a second centrifuge tube. Then sample were filtered through Whatman No. 1 filter paper. The filtered sample extracts were drained through SPE cartridge attached to an SPE vacuum manifold.

A $15 \mathrm{ml}$ graduated centrifuge tube was placed in the vacuum apparatus to serve as a collection vessel and elute oxytetracycline from the cartridge with $6 \mathrm{ml}$ elution solution. Vacuum condition was applied to initiate flow continue elution. Once flow stops, vacuum applied to remove residual solvent from the cartridge. Tubes were removed from vacuum manifold and vortex was done. The tube containing elute was placed in the sample concentrator at the temperature at 40 - $50^{\circ} \mathrm{C}$ to reduce volume of the elute to $0.5-0.25 \mathrm{ml}$ under a stream of dry nitrogen. Final volume was adjusted to $1 \mathrm{ml}$ with methanol + water $(1: 1)$ and briefly vortexing. Then approximately $1.0 \mathrm{ml}$ extract was drawn into a $3 \mathrm{ml}$ 
syringe and was filtered through a syringe into an HPLC vial $(1.5 \mathrm{ml})$. The remaining extract was stored at $-20^{\circ} \mathrm{C}$.

The concentrate extract were subjected to analysis by Agilent 1100 series HPLC system. Mobile phase was prepared by buffer and methanol at a ratio of 70 : 30, injection volume was $20 \mu \mathrm{l}$; flow rate: $1 \mathrm{ml} / \mathrm{min}$, column temperature: $30^{\circ} \mathrm{C}$, detector : fluorescence detector (Agilent 1200 series); excitation wavelength : $380 \mathrm{~nm}$; emission wavelength: $520 \mathrm{~nm}$ and run time: 12 minutes. The precision of the method was determined as recoveries of oxytetracycline spiked blank samples. For this two replicate oxytetracycline free fish samples were spiked with $150 \mathrm{ppb}$ oxytetracycline standard just before test.

Of the total 24 Thai Pangas samples obtained from the local fish markets, detectable amount of oxytetracycline residues were detected in 6 (25\%) Pangas samples (Table 1). The range of detected oxytetracycline concentrations of positive samples (Fig. 1) were between 25.05 and $50.05 \mathrm{ppb}$ (mean $=35.11 \pm$ $3.84 \mathrm{ppb})$. Whereas, Oxytetracycline residues in $18(75 \%)$ samples of Pangas were found less than the detection limit used for this study.

Table 1. Occurrences of oxytetracycline residues in Thai Pangas (Pangasianodon hypophthalmus)

\begin{tabular}{lccccc}
\hline $\begin{array}{l}\text { Samples } \\
(\mathrm{n})\end{array}$ & \multicolumn{2}{c}{ Concentration $(\mathrm{ppb})$} & \multicolumn{2}{c}{ Distribution of samples, n (\%) } & \multirow{2}{*}{$\begin{array}{c}\text { Exceed } \mathrm{MRL}^{3} \\
\mathrm{n}(\%)\end{array}$} \\
\cline { 2 - 5 } & Mean $\pm \mathrm{SEM}^{1}$ & Range & $\begin{array}{c}\text { Less than } \\
\text { LOD }\end{array}$ & $\begin{array}{c}\text { Positive samples } \\
(\text { LOD }-100 \mathrm{ppb})\end{array}$ & \\
\hline 24 & $35.11 \pm 3.84$ & $25.05-50.05$ & $18(75 \%)$ & $6(25 \%)$ & $0(0.00)$ \\
\hline
\end{tabular}

${ }^{1}$ Standard error mean. ${ }^{2} \mathrm{LOD}=$ Limit of detection $=23.62 \mathrm{ppb},{ }^{3} \mathrm{MRL}=100 \mathrm{ppb}$.

The aim of this study was to detect the presence of oxytetracycline residues in Thai Pangas fish, because fish are considered as bio-indicators of antibiotic contamination in aquatic environment. According to the results of this study, only $6(25 \%)$ Pangas fish samples were contaminated with oxytetracycline residues.

In this experiment no samples exceeded the maximum residue limits (MRL) of oxytetracycline (100 ppb) recommend by European Commission (2010). Fortt et al. (2007) detected $87 \mathrm{ppb}$ oxytetracycline in Salmon and Shim et al. (2010) also reported up to $60 \mathrm{ppb}$ of oxytetracycline residues in wild and cultured fish including olive flounder, sea bass, rock bream, yellowtail, gray mullet, gizzard shad, black rockfish, red seabream and squid caught from their natural habitat. Sharafati-Chaleshtori et al. (2013) informed presence of oxytetracycline residues in Rainbow trout (Oncorhynchus mykiss) meat after collection from the markets. 
A study of Barani and Fallah (2015) found tetracyclines residues in 138 rainbow trout muscle at a range $1.43-91.130 \mathrm{ppb}$ and only one sample (101.40 ppb) exceeded the maximum residue limit of oxytetracycline set by the European Commission.

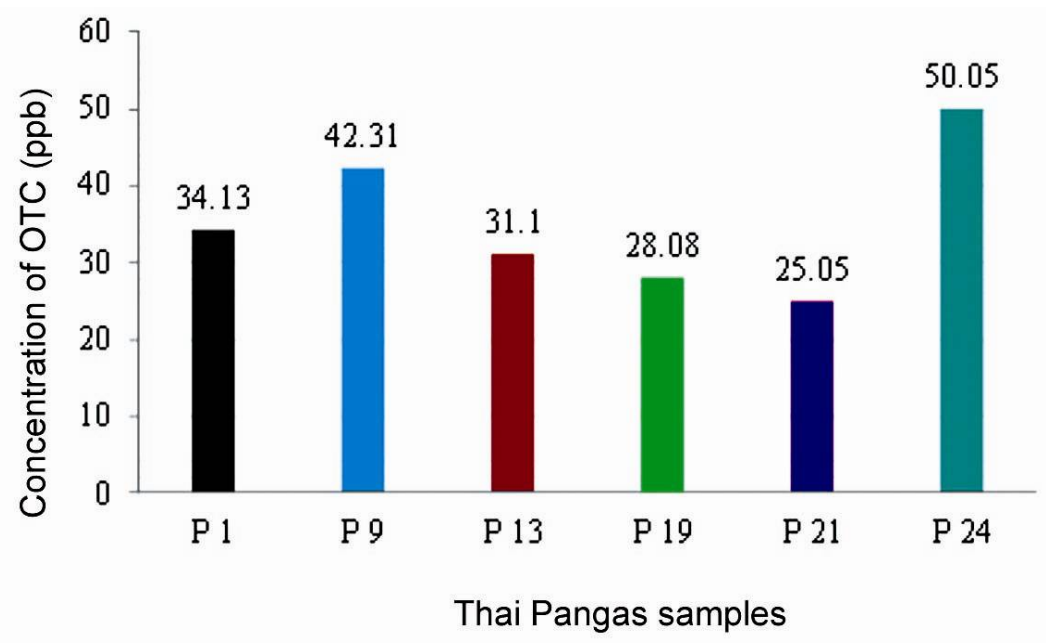

Fig. 1. Detected oxytetracycline residues in Thai Pangas.

In this study oxytetracycline residues in some sample were found below the detection limit (23.62 ppb). Baydan et al. (2015) reported that no samples of Oblada melanura and Mullus barbatus collected from the natural habitat exceeding the detection limit of oxytetracycline according to their used method. A recent study of Barani and Fallah (2015) reported tetracyclines residues in some trout samples less than the detection limit of competitive enzyme-linked immune sorbent assay method. Mahmoudi et al. (2014) also reported 8.44 \pm 6.03 $\mathrm{ppb}$ tetracyclines residues in Oncorhynchus mykiss and the confined tetracyclines residues were lower than the detection limit of present study. Turk and Oguz (2016) found no oxytetracycline in fish samples collected from Muğla province, Turkey. Shim et al. (2010) also reported no oxytetracycline residues in some examined fish during their study.

Availability of oxytetracycline residues in contaminated fish in the present study indicates indiscriminate use and avoiding of withdrawal period of this antibiotic. Though detected level of oxytetracycline in examined fish sample did not exceed the maximum residue limit (100 ppb) recommended by European Commission (2010), but in case of long term exposure with higher amount could be hazardous for public health. 
In this regard some corrective measures are required to ensure safe and antibiotic free fish for mass people. At field level, oxytetracycline use should be kept under supervision and only be used for treatment purposes in fishes with prescribed doses. Fish should be marketed only after achieving the withdrawal period. In addition awareness build up programs and regular residues monitoring of marketed fish by the government authorities are needed. Isolation of antibiotic resistance bacteria in fish and sediments of fish farming areas and antibiotics residues monitoring study of other fish species are also required.

\section{LITERATURE CITED}

ALI, H., RICO, A., MURSHED-E-JAHAN, K. and BELTON, B. 2016. An assessment of chemical and biological product use in aquaculture in Bangladesh. Aquaculture 454: 199-209.

AVSEVER, M.L., TÜRK, N. and TUNALIGIl, S. 2010. The increase of antibiotic resistance in aquaculture and its effects on human health. Bornova Veteriner Kontrolve Arastirma Enstitüsü. 32(46): 19-23.

BARANI, A. and FALLAH, A.A. 2014. Occurrence of tetracyclines, sulfonamides, fluoroquinolones and florfenicol in farmed rainbow trout in Iran. Food and Agricultural Immunology 26(3): 420429.

BAYDAN, E., KAYA, S., ÇAGIRGAN, H., YILDIRIM, E., ALTINTAS, L., YURDAKOK, B., EKICI, H., AYDIN, F.G. and KUCUKOSMANOGLU, A.G. 2015. Investigation of some veterinary drug residues in sea water, sediment, and wild fishes captured around fish farms in the Aegean Sea: Oxytetracyline, ivermectin and emamectin. Ankara Üniversitesi Veteriner Fakültesi Dergisi. 62(3): 171-176.

BEGUM, M., AKTER, T. and MINAR, M.H. 2012. Effect of salt and garlic on the quality and microbial content of smoked catfish (Pangasianodon hypophthalmus). International Journal of Bio-resource and Stress Management 3(4): 464-467.

BELTON, B., KARIM, M., THILSTED, S., JAHAN, K.M., COLLIS, W. and PHILLIPS, M. 2011. Review of Aquaculture and Fish Consumption in Bangladesh. Studies and Reviews 2011-53. The WorldFish Center, Penang, Malaysia. 71 pp.

ERDOGDU, A.T. 2012. Using antibiotics in aquatic living beings. Rational use of antibiotics and antimicrobial resistance symposium, Ankara, Turkey. pp. 87-95.

EUROPEAN COMMISSION. 2010. Commission Regulation (EU) No. 37/2010 of 22 December 2009 on pharmacologically active substances and their classification regarding maximum residue limits in foodstuffs of animal origin. Official Journal of the European Union L15. 72 pp.

FAO/WHO. 2003. Code of practice for fish and fishery products. Codex Alimentarius Commission. CAC/RCP. 52-2003, Rev. 2-2005. 242 pp.

FORTT, Z.A., CABELLO C.F. and BUSCHMANN, R.A. 2007. Residues of tetracycline and quinolones in wild fish living around a salmon aquaculture center in Chile. Revistachilena de infectologia: organooficial de la Sociedad Chilena de Infectologia 24(1): 14-18.

HEUER, O.E., KRUSE, H., GRAVE. K., COLLIGNON, P., KARUNASAGAR, I. and ANGULO, F.J. 2009. Human health consequences of use of antimicrobial agents in aquaculture. Clinical Infectious Diseases 49(8): 1248-1253.

MAHMOUDI, R., GAJARBEYGI, P., NORIAN, R. and FARHOODI, K. 2014. Chloramphenicol, sulfonamide and tetracycline residues in cultured rainbow trout meat (Oncorhynchus mykiss). Bulgarian Journal of Veterinary Medicine 17(2): 147-152. 
SAPKOTA, A., SAPKOTA, A.R., KUCHARSKI, M., BURKE, J., MCKENZIE, S., WALKER, P. and LAWRENCE, R. 2008. Aquaculture practices and potential human health risks: current knowledge and future priorities. Environment International 34(8): 1215-1226.

SHARAFATI-CHALESHTORI, R., MARDANI, G., RAFIEIAN-KOPAEI, M., SHARAFATI-CHALESHTORI, A. and DREES, F. 2013. Residues of oxytetracycline in cultured rainbow trout. Pakistan Journal of Biological Science 16(21): 1419-1422.

SHIM, K.B., MOK, J.S., JO, M.R., KIM, P.H., LEE, T.S., KIM, J.H. and CHO, Y.J. 2010. Residues of antibiotics in wild and cultured fishes collected from coast of Korea. Korean Journal of Fisheries and Aquatic Sciences 43(1): 12-17.

TURK, E. and OGUZ, H. 2016. Investigation of tetracycline residues in fish caught from surrounding fish farms in Muğla district. Eurasian Journal of Veterinary Sciences 32(2): 74-79. 